\title{
"Double duck" nasolabial lifting
}

\section{Lifting nasolabial com realce do vermelhão}

Vera Lucia Nocchi Cardim ${ }^{1}$

Alessandra dos Santos

SILVA $^{2}$

Rolf LuCas SALOMONS ${ }^{2}$

Rodrigo de Faria Valle

DORNELLES ${ }^{3}$

José Orlofe de Souza

$\mathrm{BLOM}^{4}$

Adriano de Lima e Silva ${ }^{2}$

Study conducted at Núcleo de Plástica Avançada (NPA), São Paulo, SP, Brazil.

Submitted to SGP (Sistema de Gestão de Publicações/Manager Publications System) of RBCP (Revista Brasileira de Cirurgia Plástica/Brazilian Journal of Plastic Surgery).

Received: April 3, 2011 Accepted: August 14, 2011

\begin{abstract}
Background: During aging, the vermilion border of the upper lip wrinkles, stretches, and inverts because of the sphincteric action of the orbicularis oris muscle. Furthermore, a decrease of the nasolabial angle can be observed because of maxillary retropositioning. Most techniques for lip shortening do not affect this angle. In this study, a treatment approach is proposed that addresses all of these signs of aging. Methods: During a 1-year period, a procedure was performed on 10 patients using the following techniques: 1 . transverse incision of the skin of the nasal floor and bilateral alar margin; 2. cutaneous detachment of the entire upper lip up to the mucocutaneous transition; 3 . stabilization of the nostrils with a transcolumellar nylon stitch; 4. elevation of the released skin by elliptical skin resection at the alar margin and a trapezoid segment resection at the nasal floor; 5. use of nylon and absorbable sutures to approach the dermis and close the skin, respectively. Results: Adequate results were observed in 9 of the 10 patients, characterized by shortening and projection of the upper lip, vermilion eversion, reduced incidence of rhagades, and improvements of the nasolabial angle. In 1 patient with unilateral paralysis of the lip, no significant correction of the asymmetry was achieved. Conclusions: The proposed "double duck" technique proved to be simple and effective, with successful resolution of nasolabial defects and effective concealment of scars.
\end{abstract}

Keywords: Lip/surgery. Removal. Aging. Plastic Surgery/methods.

\section{RESUMO}

Introdução: Durante o envelhecimento, o lábio superior sofre enrugamento, alongamento e inversão do vermelhão, em decorrência da ação esfinctérica do músculo orbicular dos lábios. Além disso, a retrusão da parede anterior da maxila provoca diminuição do ângulo nasolabial. A maioria das técnicas para encurtamento labial não obtém a abertura desse ângulo. Neste trabalho, é proposta uma abordagem que contemple o tratamento de todos esses sinais de envelhecimento. Método: No período de um ano, foram operados 10 pacientes pela seguinte técnica: 1. incisão transversa da pele do assoalho nasal e margem alar bilateral; 2 . descolamento cutâneo de todo o lábio superior até a transição cutaneomucosa; 3. estabilização das asas nasais com ponto transcolumelar; 4. elevação da pele descolada, com ressecção elíptica do segmento justa-alar e trapezoide do segmento do assoalho nasal; e 5. suturas dérmica, com fio de náilon, e epidérmica, com fio absorvível. Resultados: Encurtamento e projeção do lábio com eversão do vermelhão, diminuição das rágades e abertura do ângulo nasolabial adequados foram obtidos em 9 dos 10 pacientes. Em um paciente que apresentava paralisia unilateral do lábio, não houve correção significativa da assimetria. Conclusões: A técnica proposta mostrou-se de simples realização, de resolução efetiva dos objetivos e com boa ocultação das cicatrizes.

Descritores: Lábio/cirurgia. Remoção. Envelhecimento. Cirurgia plástica/métodos.

1. Plastic Surgeon, Doctor of Concentration in General Surgery at the School of Medical Sciences of Santa Casa de São Paulo (FCMSCSP), post-doctoral at FCMSCSP, Full member of the Brazilian Society of Plastic Surgery (SBCP) and the Brazilian Association of Cranio-Maxillofacial Surgery (ABCCMF), Doctor in charge of the Non-Masters Postgraduate Course on Craniofacial Surgery of Beneficiência Portuguesa of São Paulo and of the Department of Plastic Surgery - Center for Advanced Plastic (NPA), São Paulo, SP, Brazil.

2. Plastic Surgeon, Full member of the SBCP and ABCCMF, Medical assistant at NPA, São Paulo, SP, Brazil.

3. Plastic Surgeon, Full Member of the SBCP and ABCCMF, Master of Plastic Surgery at the School of Medicine, Universidade de São Paulo (USP), Physician Assistant at NPA, São Paulo, SP, Brazil.

4. Plastic Surgeon, Associate Member of the SBCP, São Paulo, SP, Brazil. 


\section{INTRODUCTION}

Aging leads to some predictable outcomes in the center of the face if the effects of bone remodeling, muscle flaccidity, and loss of skin elasticity are considered. The natural anatomy and shape of the upper and lower lips have been previously described ${ }^{1}$.

The action of the mimic muscle over the piriformis area exerts pressure on the bone structure of the maxillary anterior wall and on the piriformis fossa. Subsequent progressive retropositioning of the middle third of the face causes, not only a relative increase in the anterior projection of the nose, but also a fall in the nasal tip, thereby resulting in a reduction of the nasolabial angle.

The centripetal work performed by the orbicularis strap in lip sealing, associated with the loss of skin elasticity, causes progressive vertical stretching of the upper lip, and thereby narrowing the vermilion. Therefore, fall of the nasal tip and stretching of the upper lip are unequivocal features of aging. When present in young faces due to hereditary or personal factors, these defects indicate premature aging or aesthetic disharmony.

With age, the upper lip undergoes changes that obstruct a clear view of the patient's teeth ${ }^{2}$. The loss of lip volume and architecture, coupled with lip descent, promotes loss of visualization of the upper teeth, while external rotation suffered by the lower lip enables visualization of the lower teeth, leading to an aged appearance ${ }^{3}$.

There is universal agreement on these principles, and treatment methods are numerous, ranging from less invasive procedures that aim to improve the quality of skin coverage to more invasive surgeries that aim to reduce the vertical dimension of the upper lip skin, and different types of fillings.

The primary goals of the proposed treatment methods for senile lip are volume correction and shape correction ${ }^{4}$. Fillings and autologous (fat and dermal fat) grafts $^{5}$ are used for volume correction, while lip shortening and/or increased exposure of the vermilion are used for shape correction. Additionally, some investigators have sought to correct these defects using techniques that involve the advancement of the wet portion of the labial mucosa, nasal base resection ${ }^{2,4,6}$ in mucocutaneous transition ${ }^{7,8}$, or even in nasolabial folds?.

In most cases, a combination of approaches is required in the alar base and in mucocutaneous transition, aiming at promoting lip rotation, exposing the vermilion, and improving fine skin wrinkles ${ }^{4,10}$. Some investigators use additional procedures, including surgery ${ }^{11}$. Haworth ${ }^{10}$ proposed an algorithm for global treatment, noting the need for lip filling and the removal of wrinkles.

With an appreciation of the role of nasolabial angle impairment during the lip aging process, Haddad Filho et al. ${ }^{12}$ proposed applying a patch of dry skin near the base of the nostrils, using the buffalo horn technique to embed de-epithelialized and medially pedicled skin into the columella. This procedure causes an opening of the nasolabial angle and vertical projection of the columella.

In order to solve the defects associated with senile lip for maximum effectiveness, an alternate approach is presented here. This study aims to shorten the upper lip by skin detachment, which upon removal, causes lip volume rotation along with a projection and enhancement of the vermilion. Skin resection in the alar implant and in the nose floor aims to virtually eliminate visible scars while preserving the columella. These resections cause a redundancy of skin at the base of the columella, which automatically opens the nasolabial angle, slightly elevating the nasal tip; such an elevation is comparable in width to the columellar region detachment between the medial crux.

\section{METHODS}

Between July 2009 and August 2010, 10 patients underwent surgery ( 9 women and 1 man), at a mean age of 55.2 years (range, 48-66 years).

The inclusion criterion for this study was excessive vertical dimension of the upper lip skin, with thinning of the vermilion. Labial reduction was the primary intervention in 9 patients and a secondary intervention in 1 patient, where lip-shortening surgery had been performed 4 years earlier. In $40 \%$ of cases, earlier application of permanent fillers had been reported. The sole male patient developed unilateral associated paralysis as a sequela of a previous orthognathic surgery.

In cases where the nasolabial technique alone was applied, local anesthesia was used with 2\% lidocaine and 1:200,000 epinephrine. When the technique was applied alongside rhytidoplasty under general anesthesia, local infiltration was performed with levobupivacaine and 1:200,000 epinephrine.

The design of the incision, covering the nasal floor from the base of the columella and encircling the alar in its skin groove was consistent with the desired skin resection and met the requirement for lip shortening. The bottom line of the design can be tattooed in bright green with an insulin needle, but never incised simultaneously with the proximal incision (Figure 1).

After an incision along the proximal lines of the drawings, the skin around the upper lip was detached (Figure 2). The deep dermis was separated from its insertion point in the orbicularis muscle side-by-side through the filtrum with the mucocutaneous line of the vermilion delineating the lower limit, which corresponded to the point that would be rotated upwards when the skin was shortened (Figures 3 and 4). 


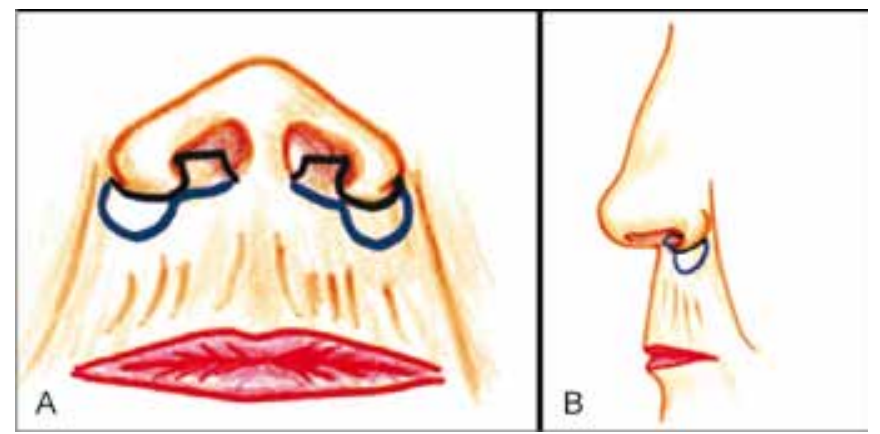

Figure 1 -Demarcation of incisions at the nasal base, front $(\boldsymbol{A})$, and profile $(\boldsymbol{B})$.

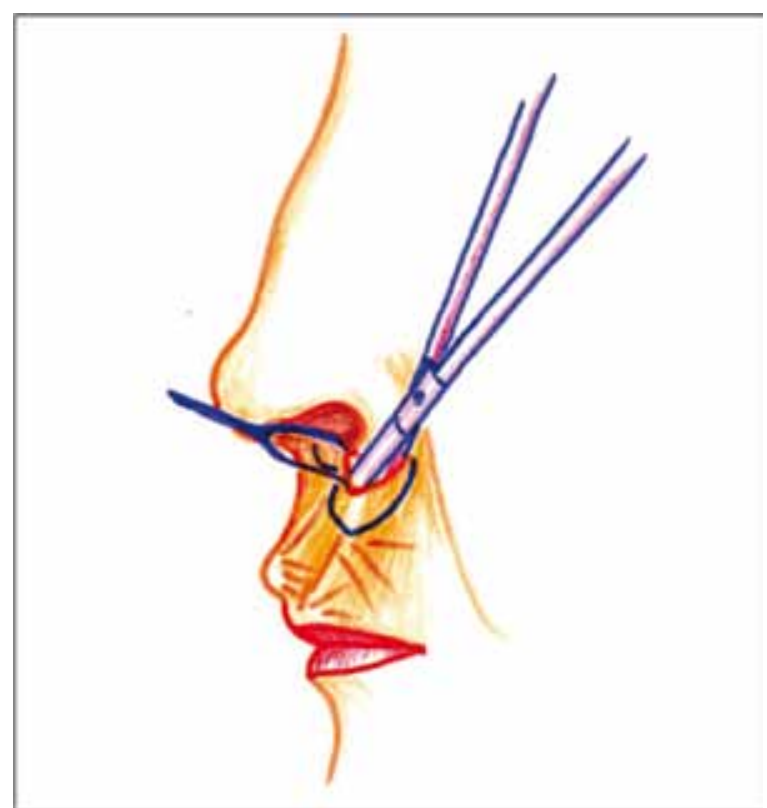

Figure 2 -Detachment of the upper lip skin along its entire length, with the vermilion mucocutaneous line as a lower limit.

Skin redundancy at the columellar base caused a slight elevation of the nasal tip, a result of ears formed by bilateral skin excision on the nasal floor. In cases of a closed nasolabial angle, an intercartilaginous detachment can be performed with Fomon scissors between the medial crux continuing along the entire tip of the nose between the alar and triangular, to induce nasal tip repositioning in an upwards rotation (Figure 5). The fixing was performed with transfixing stitches of simple catgut 4-0 in the columella, at the medial crux and the distal margin of the quadrangular cartilage.

One deep stitch of Mononylon 3-0 was passed across the nasal base, relying on the alar skin and respecting the original width of the nose. This stitch, which passes behind the columella along the thickness of the lip, stabilizes the

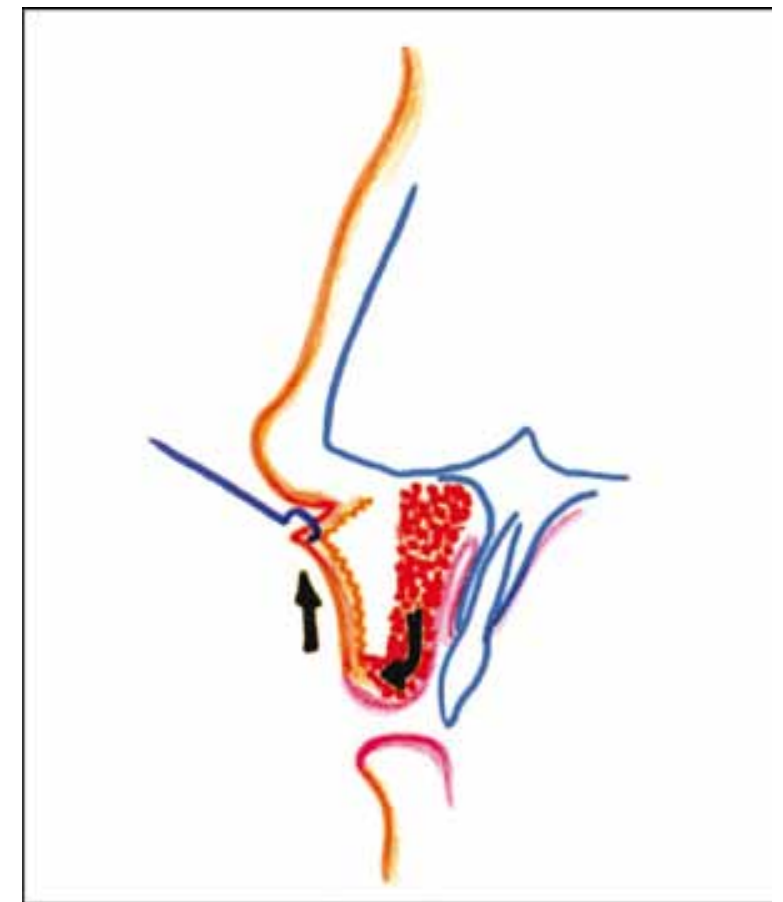

Figure 3 -Rotation of the posterior plane (muscle) due to the shortening of the anterior plane (skin).

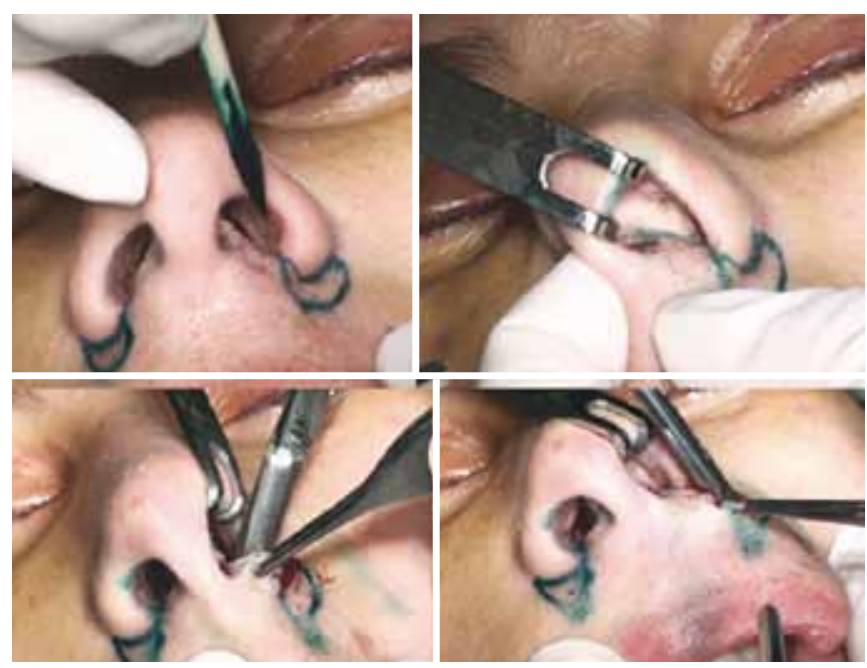

Figure 4 -Demarcation and skin detachment.

nasal alar so that it is not distorted or erased as it receives the suture traction of the lip flap margins (Figure 6). After careful hemostasis, the skin was vertically pulled, confirming the previously projected amount of resection in the design, or modified as needed.

After excision, the margins of the lip flap were lifted to the proximal margins in the alar implant with Halsted stitches using Mononylon 5-0 (Figure 7). 


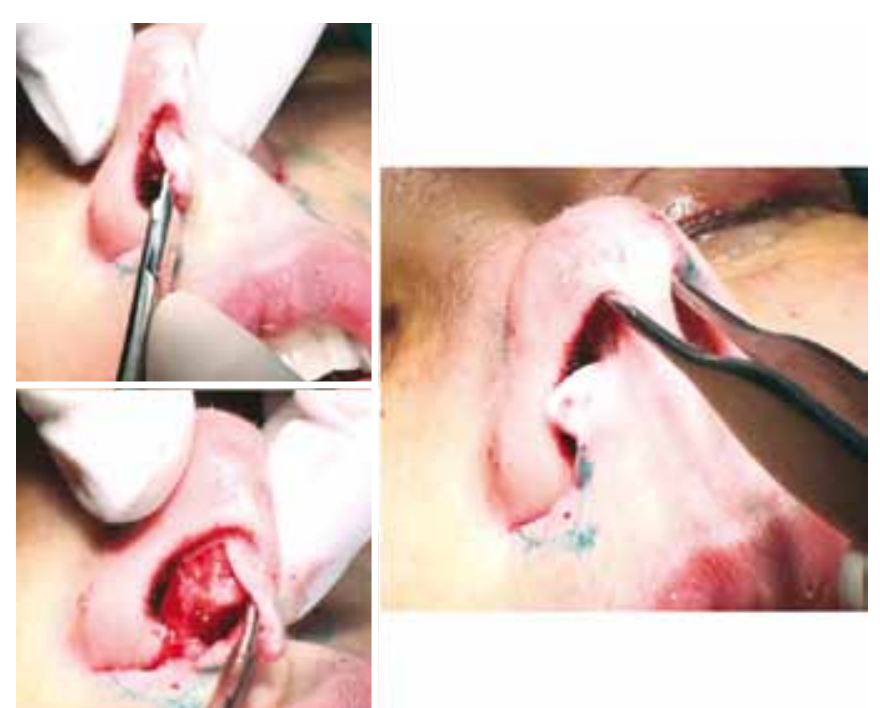

Figure 5 - Intercrural detachment of the columella, previously mobilizing the nasal tip.
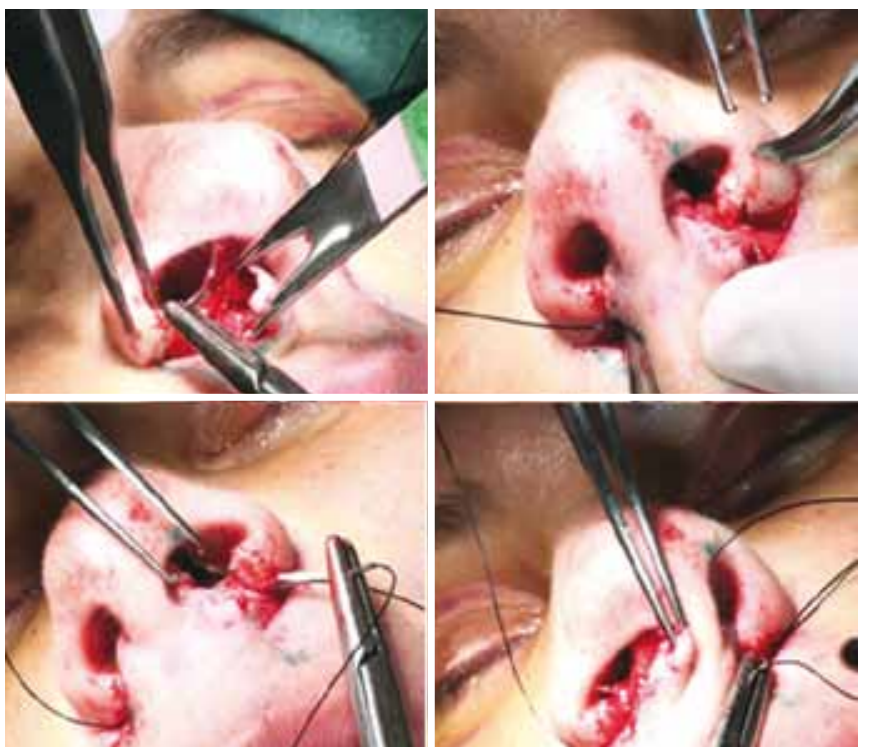

Figure 6-Alar stabilizer point (nose width).

As lip shortening is stabilized with the distal suture, the medial segments of the nasal floor were resected, enabling final continuous suturing with Monocryl 5-0 (Figure 8).

After immobilizing the lip with a micropore, mattress stitches were made with Mononylon4-0, removingmaximum amount of muscle tissue with the support and protection of the dressing tape. This procedure was performed predominately to keep the lower rotation of the posterior plane of the lip, but also to avoid dead space. This immobilization revealed all excesses in length of the lip along the vermilion mucocutaneous line, causing lip rotation and enlargement (Figure 9). As the lip is very mobile, these transfixing

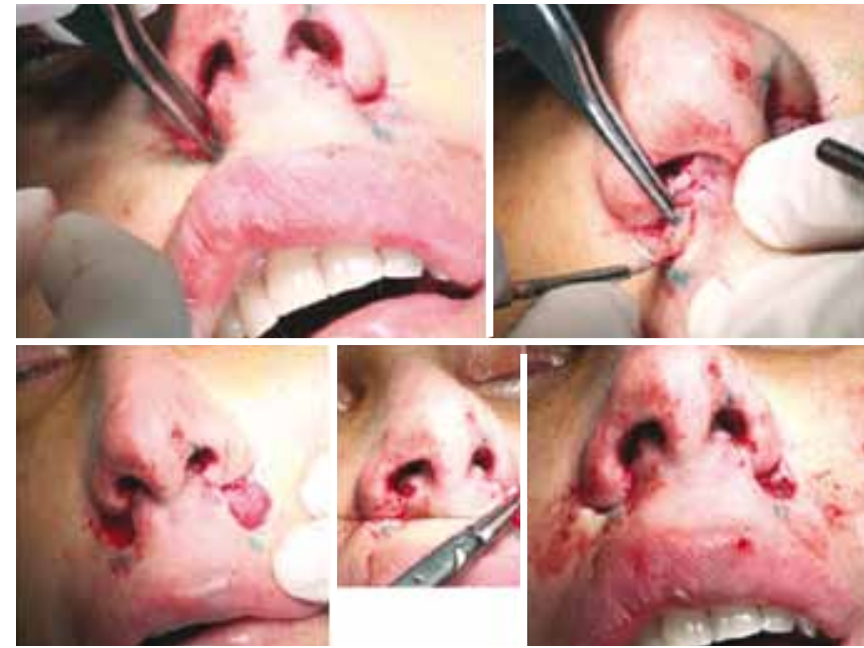

Figure 7 -Reassessment of the amount of tissue to be resected, excision of lip skin distal portions, and repairing edges with Halsted stitches.
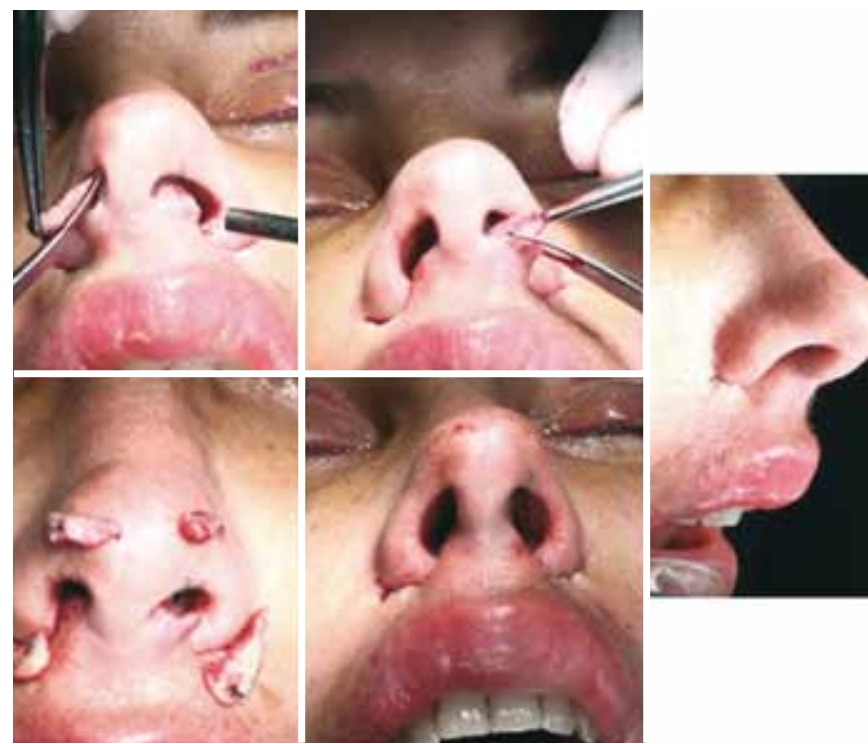

Figure 8 -Excision of medial portions of the lip flap, resected skin fragments, and the immediate result: nasal tip projection, shortening and central projection of the lip.

sutures remained in place for 4 days after the surgery to ensure minimal scarring.

\section{RESULTS}

The intended results were achieved in 9 patients, for both the lip and the nasal tip. In the patient with unilateral paralysis, however, there was no significant improvement after the procedure. 
There were no hematomas, necroses, paralyses, or permanent anesthesias in any case. Edema was intense during the first 4 days postoperatively. In 8 out of 10 cases, any evident edema was resolved in 8 to 9 days. In 1 case where generous pre-filling with liquid silicone and polymethylmethacrylate (PMMA) occurred in the lip and nasolabial folds, the inflammatory edema lasted for about 30 days. After this period, recovery was comparable to the other cases. The only other case of delayed resolution of edema was in the sole male patient who previously contracted unilateral paralysis. On the affected side, stasis and lymphedema accounted for the nullification effect observed with the intended shortening of the lip, maintaining the initial lip asymmetry.

The full mobility and sensitivity of the upper lip was regained in 2 to 3 weeks after surgery, except for the 2 aforementioned cases of a prolonged edematous phase, in which the return of sensitivity was directly proportional to the pace of edema regression.

\section{DISCUSSION}

For over 20 years, vertical shortening of the upper lip has been performed with a technique which is very similar to the "double duck" procedure presented here. The incision line was a variation of the buffalo horn, in which, instead of resecting the skin under the nose implant, the incision was housed within the nasal floor, down to the nose base in the alar implant and at the columellar base (Figure 10). Avoidance of lip volume rotation with
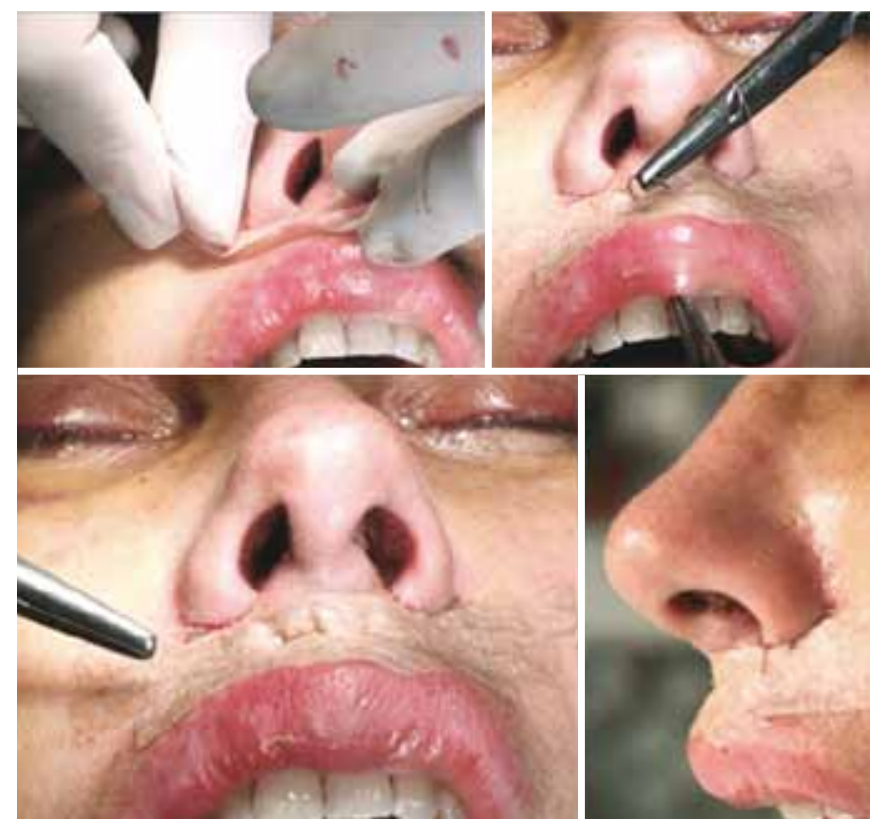

Figure 9-Healing with transfixing stitches encompassing both detached tissue layers, in order to maintain the vermilion eversion. greater exposure of the vermilion was the primary focus of the procedure. For this purpose, all upper lip skin was detached up to the mucocutaneous line at the skin flap base and at the rotation point that determines increasing vermilion (Figure 11). Within this routine, all types of care protocols with alar implant stabilization are utilized (e.g., nylon 3-0 transfixing stitch at the nasal base), including a dressing procedure that immobilizes the rotation of the lip posterior plane. The resulting scar, however, passed through the columellar base. This issue alone does not

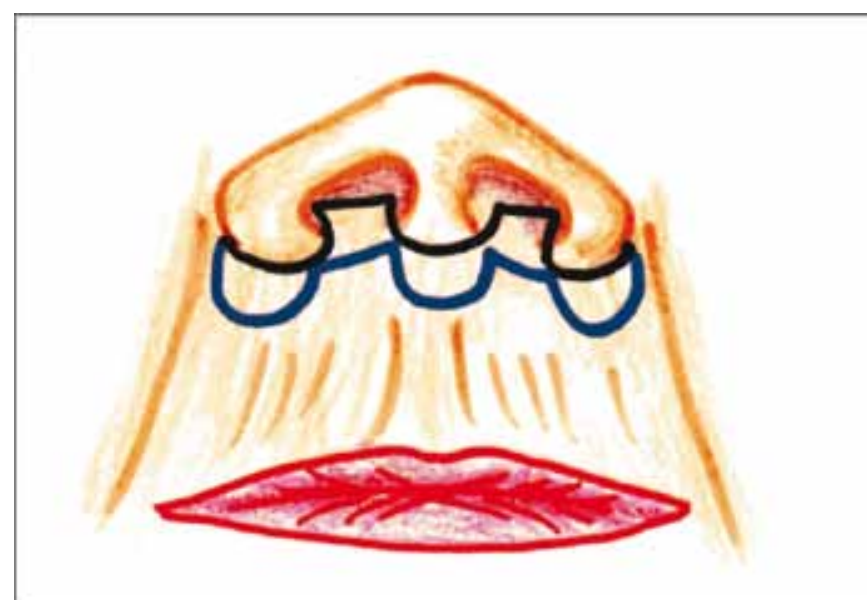

Figure 10 - Previous incision practiced by the authors, which was the basis for the evolution of the proposed technique.

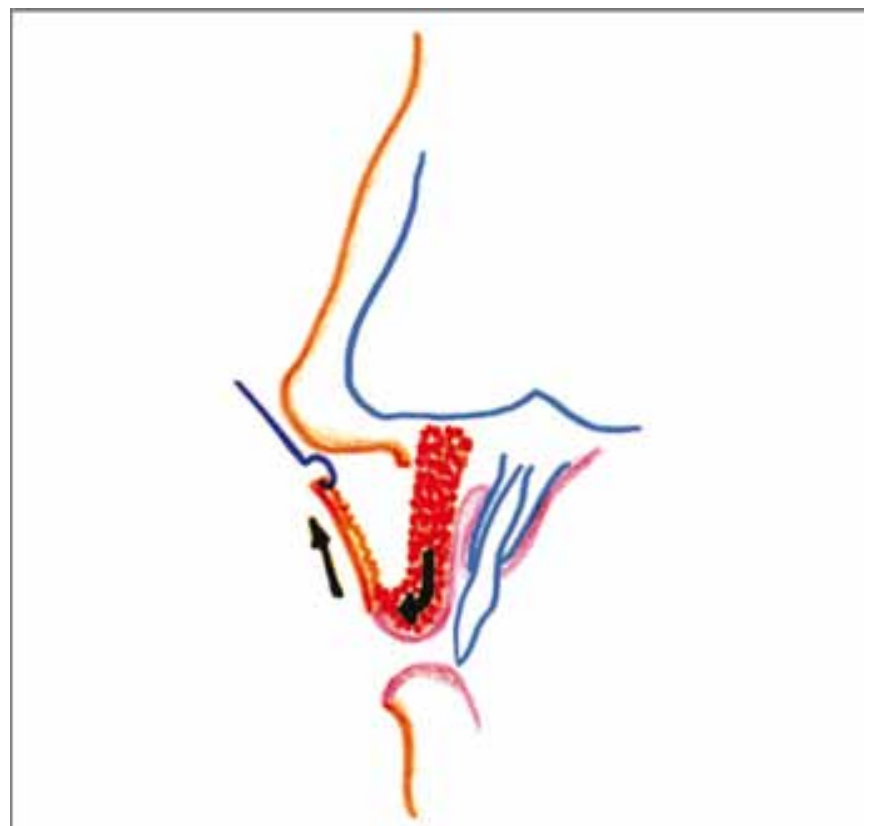

Figure 11 -Detachment, already practiced in the initial technique, resulting in plane rotation and vermilion eversion. 
have a significant impact on procedure effectiveness, considering that the scar is situated in a natural fold, and more exposed scars in the columella that occur after open rhinoplasty are accepted quite naturally, as though they were inevitable. The drawback in continuing with skin resection under the columella is that the procedure's effectiveness is limited to the lip; it does not result in any benefit to the nose or nasolabial angle. This is true despite the fact that both procedures remove the same amount of skin at this central point, which is required for the overall shortening of the lip. Haddad Filho et al. ${ }^{12}$ also do not project the nasal tip, as the skin strip under the columella is located between the 2 sides of the incision and is not used in the anteroposterior stretching of the columella.

With an understanding of the rejuvenating effects of increasing the nasolabial angle and the efforts of other investigators in search of this effect ${ }^{3}$, the skin resection in the central region corresponding to the columellar base was halted. In addition to eliminating the scar in this area, a skin redundancy was produced at the center of the nasolabial angle, due to resections performed at the base of the nostrils. This tissue redundancy causes columellar stretching, and, if accompanied by a intercartilaginous detachment of the nasal tip, columellar redistribution throughout this region, providing an effective rotation of the nasal tip.

The upwards rotation effect of the vermilion was achieved by skin traction, which was detached until the mucocutaneous margin. Investigators who advocate skin resection with mucocutaneous transition have the same objective of increasing the exposure of the vermilion. However, our procedure differs in that, by moving the scar to the nasal floor, a reduction in lip wrinkles is achieved by cutaneous detachment, in addition to maintaining this transition without visible scars.

The traction dissociated from tissue planes (shortening only the skin to enable the anterior turn of lip volume) is what differentiates these techniques from those proposed by Santanchè \& Bonarrigo ${ }^{7}$. These investigators, upon resection of the lip muscle en bloc at its upper base, also acquired lip shortening en bloc; the increasing vermilion only corresponds to the accommodation of excess moist mucus. Santanchè \& Bonarrigo propose a skin resection very similar to that presented here, but their technique does not result in a nasal angle increase due to muscle emptying at the columellar base.

\section{CONCLUSION}

The proposed "double duck" technique was effective for upper lip shortening by producing a hidden scar at the nasal floor and alar base groove. Skin detachment enabled the surgeon to locate the rotation point of the vermilion in the mucocutaneous transition, in addition to concealing lip wrinkles. Skin redundancy at the columellar base increased the nasolabial angle and allowed discrete projection of the nasal tip.

\section{ACKNOWLEDGMENTS}

We thank our colleague Mr. Newton Roldão (São Paulo, Brazil) for his suggestion that we name the technique presented "double duck" because of the shape of the proposed incisions.

\section{REFERENCES}

1. Perenack J. Treatment options to optimize display of anterior dental aesthetics in the patient with the aged lip. J Oral Maxillofac Surg. 2005;63(11):1634-41.

2. Austin HW. The lip lift. Plast Reconstr Surg. 1986;77(6):990-4.

3. Austin HW, Weston GW. Rejuvenation of the aging mouth. Clin Plast Surg. 1992;19(2):511-24.

4. Niechajev I. Lip enhancement: surgical alternatives and histologic aspects. Plast Reconstr Surg. 2000;105(3):1173-83.

5. Fanous N. Correction of thin lips: "lip lift". Plast Reconstr Surg. 1984;74(1):33-41.

6. Ramirez OM, Khan AS, Robertson KM. The upper lip lift using the 'bull's horn' approach. J Drugs Dermatol. 2003;2(3):303-6.

7. Santanchè $P$, Bonarrigo $C$. Lifting of the upper lip: personal technique. Plast Reconstr Surg. 2004;113(6):1828-35.

8. Pitanguy I. Ancillary procedures in face-lifting. Clin Plast Surg. 1978;5(1):51-69.

9. Marques A, Brenda E. Lifting the upper lip using a single extensive incision. Br J Plast Surg. 1994;47(1):50-3.

10. Haworth RD. Customizing perioral enhancement to obtain ideal lip aesthetics: combining both lip voluming and reshaping procedures by means of an algorithmic approach. Plast Reconstr Surg. 2004;113(7):2182-93.

11. Lessa S, Sebastiá R, Toledo O. Lábio senil. Rev Bras Cir. 1983;73(5):279-82.

12. Haddad Filho DH, Alonso N, Oksman D, Wulkan M, Godoy P. Surgical treatment of the acute columellar-labial angle. Aesthet Surg J. 2008;28(6):627-30

\section{Correspondence to: $\quad$ Vera Lúcia Nocchi Cardim}

Rua Augusta, 2709 - conj. 42 - Cerqueira César - São Paulo, SP, Brazil - CEP 01413-100

E-mail: vera@npa.med.br 